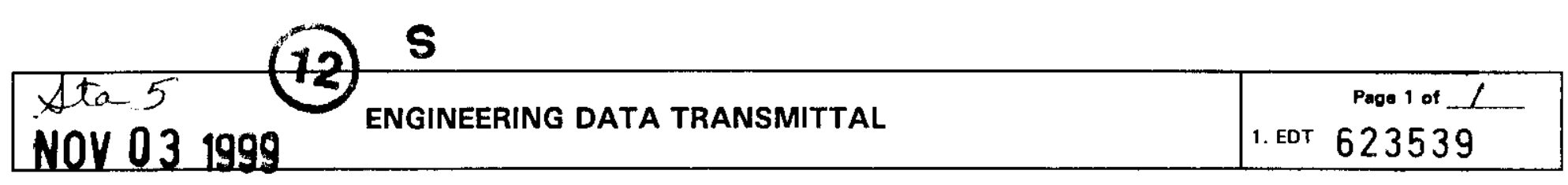

2. To: (Receiving Organization)

5. Proj./Prog./Dept./Div.:

WRAP / AJ 60

8. Originator Remarks:

This EDT is to release supporting documentation for the WRAP

Facility to Engineering Eiles for retention and retrieval.

11. Receiver Remarks:

11A. Design Baseline Document? $O$ Yes

No
Distribution

4. Related EDT No:

$\mathrm{N} / \mathrm{A}$

7. Purchase Order No:

$\mathrm{N} / \mathrm{A}$

9. Equip./Component No.:

$N / A$

10. System/B/dg./Facility:

$$
\text { 2336-W }
$$

12. Major Assm. Dwg. No.:

$\mathrm{N} / \mathrm{A}$

13. Permit/Permit Application No.:

$\mathrm{N} / \mathrm{A}$

14. Required Response Date:

$\mathrm{N} / \mathrm{A}$

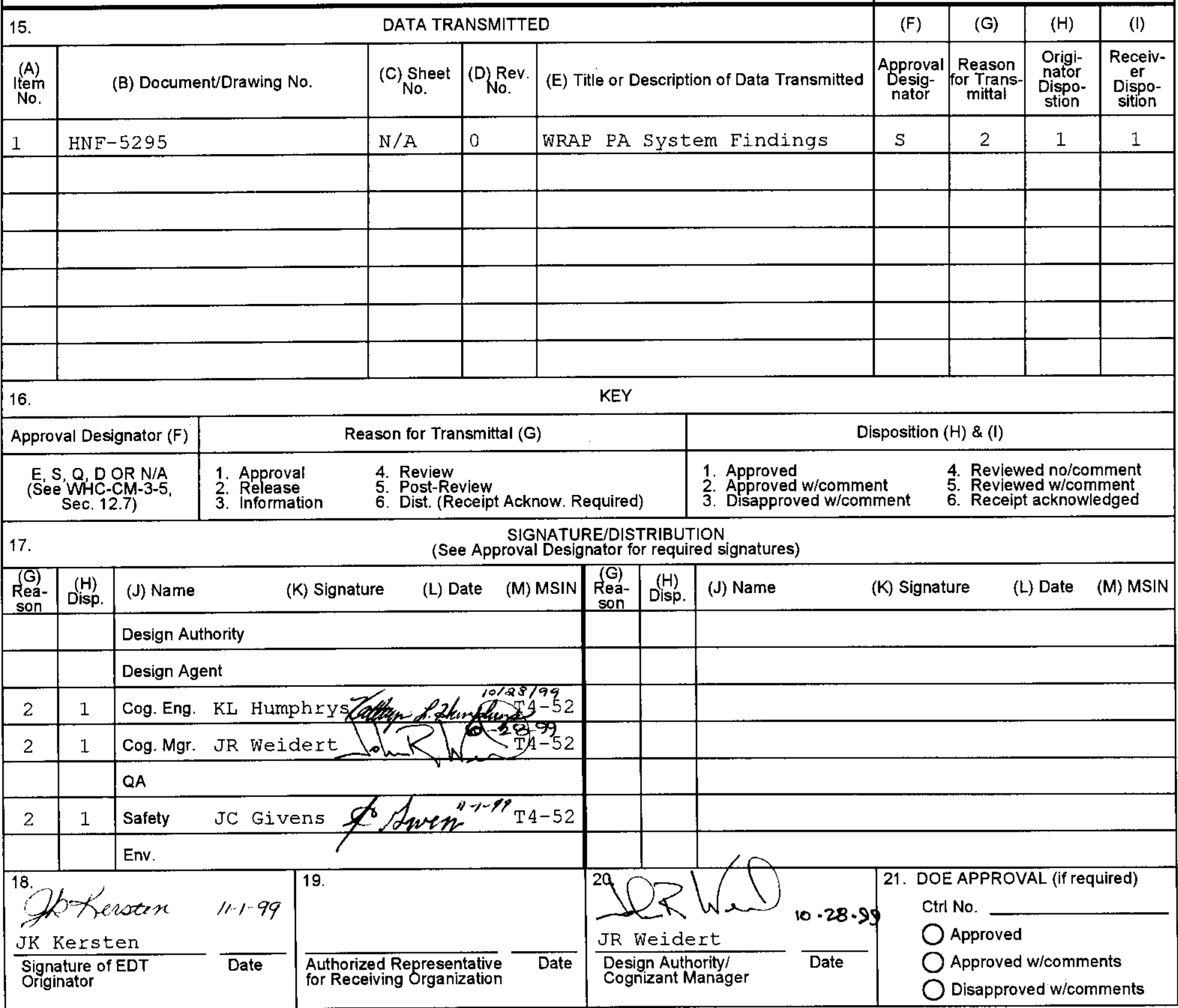




\title{
Waste Receiving And Processing Facility PUBLIC ADDRESS SYSTEM REVIEW FINDINGS
}

\author{
KL Humphrys \\ U.S. Department of Energy Contract DE-AC06-96RL13200 \\ EDT/ECN : $\quad$ EDT-623539 UC: 506 \\ Org Code: 32600 \\ B\&R Code: EW02J16 \\ Charge Code: AJ60 \\ Total Pages: 38
}

Waste Management Federal Services of Hanford, Inc., Richland, WA 99352

Key Words: Wrap, PA, ORR, SOUND SOLUTIONS NORTHWEST

Abstract: Public address system operation at the WRAP facility was reviewed. The review was based on an Operational Readiness Review finding that pub1ic address performance was not adequate in parts of the the WRAP facility.

** Minitab is a registered trademark of Minitab Inc., State College, PA.

** Valcom is a registered trademark of Valcom, Inc., Roanoke, VA.

** Windows is a registered trademark of Microsoft Corp., Redmond, WA.

TRADEMARK DISCLAIMER. Reference herein to any specific comercial product, process, or service by trade name, trademark, manufacturer, or otherwise, does not necessarily constitute or imply its endorsement, recommendation, or favoring by the United States Government or any agency thereof or its contractors or subcontractors.

Printed in the United States of America. To obtain copies of this document, contact: Document Control Services, P.O. Box 950, Mailstop H6-08, Richland WA 99352, Phone (509) 372-2420; Fax (509) 376-4989.

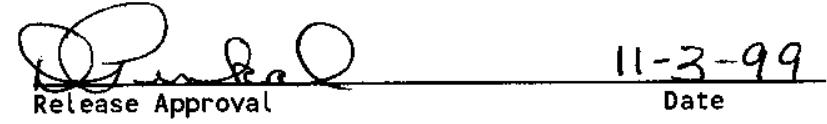

Rel ease Approval

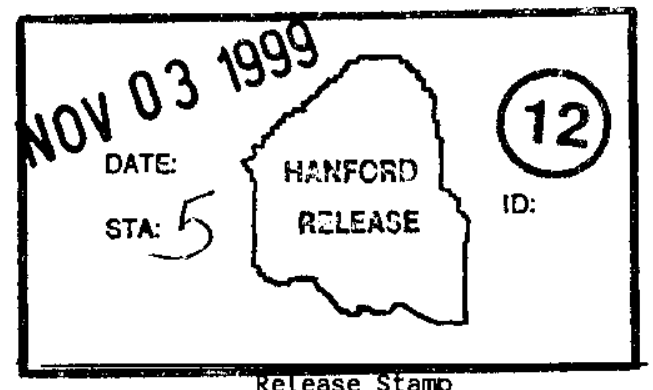

Retease stamp

\section{Approved for Public Release}


Waste Receiving and Processing Facility

\section{Public Address System Review Findings}

John R. Weidert

Kathryn L. Humphrys

Robert E. Mitchell

Michael P. Lane 


\section{Technical Abstract}

Public address system operation at the Waste Receiving and Processing (WRAP) facility was reviewed. The review was based on an Operational Readiness Review finding that public address performance was not adequate in parts of the WRAP facility.

Several improvements were made to the WRAP Public Address (PA) system to correct the deficiencies noted. Speaker gain and position was optimized. A speech processor was installed to boost intelligibility in high noise areas. Additional speakers were added to improve coverage in the work areas ${ }^{1}$.

The results of this evaluation indicate that further PA system enhancements are not warranted. Additional speakers cannot compensate for the high background sound and high reverberation levels found in the work areas. Recommendations to improve PA system intelligibility include minor speaker adjustments, enhanced PA announcement techniques, and the use of sound reduction and abatement techniques where economically feasible. 
HNF-5295 Rev. 0

Table of Contents

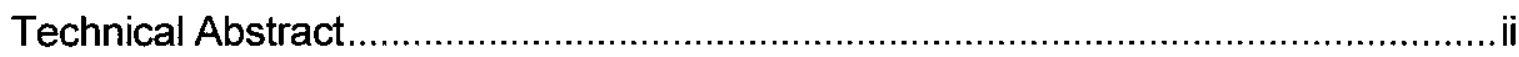

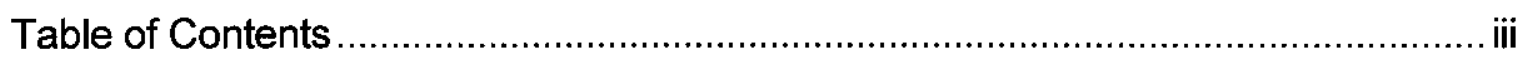

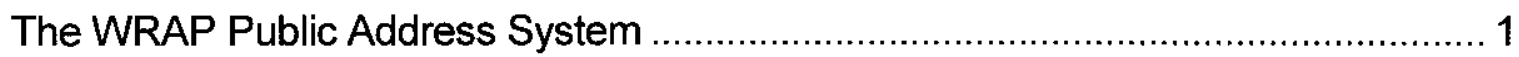

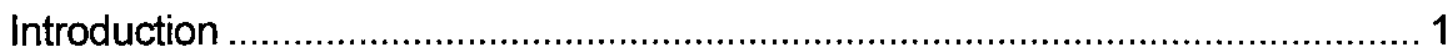

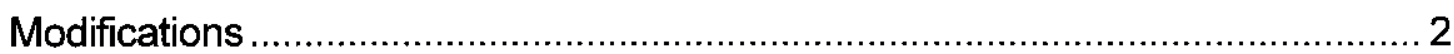

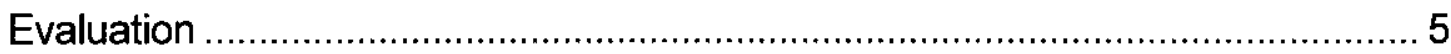

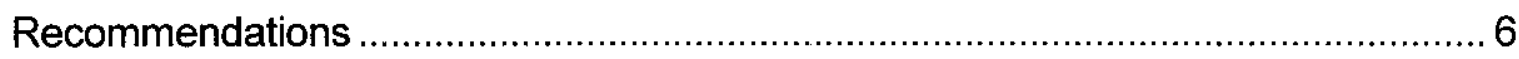

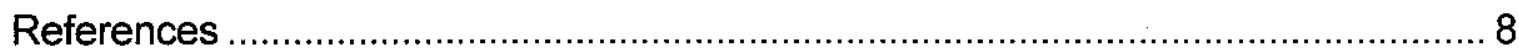

Appendix A _- Public Address System Evaluation Results .....................................A-1

Appendix B -- Public Address System Correspondence ......................................... 


\section{The WRAP Public Address System}

\section{Introduction}

The WRAP Public Address (PA) System is used to broadcast high priority and emergency messages throughout the WRAP facility. The system is accessible from any telephone located in the WRAP complex by dialing " $500-1200$ " followed by a zone number. Table 1 - "WRAP Public Address Zones" lists the WRAP public address zones.

Table 1 - "WRAP Public Address Zones"

\begin{tabular}{|c|l|}
\hline Zone & \multicolumn{1}{|c|}{ Description } \\
\hline $\mathbf{0}$ & "All-Call", Access All 6 Zones \\
\hline $\mathbf{1}$ & $\begin{array}{l}\text { Primary Work Areas: } \\
\text { Shipping/Receiving, NDE/NDA, Process Area, Process } \\
\text { HVAC, Computer Room, Material Preparation, and } \\
\text { Telecommunications room }\end{array}$ \\
\hline $\mathbf{2}$ & Other WRAP areas, storage rooms, and loading dock. \\
\hline 3 & $\begin{array}{l}\text { 2336W Administrative area, lunchroom, and conference } \\
\text { room. }\end{array}$ \\
\hline $\mathbf{4}$ & Control room and managers' offices. \\
\hline $\mathbf{5}$ & 2740 W Building \\
\hline 6 & 2620 W Building \\
\hline
\end{tabular}




\section{HNF-5295 Rev. 0}

Public address speakers are located in nearly every room in the WRAP facility (2336W), the WRAP administrative office (2740W), and the WRAP maintenance shop $(2620 \mathrm{~W})$. The speakers are powered by 24 -volt DC power supplies located in the telecommunications room of each building. Three types of PA system speakers are installed, depending on the required use. In large work areas, 5 and 15 watt horns are used to provide wider coverage. Ceiling-mounted cone speakers are used to cover administrative areas. Box speakers are used in stairwells to balance PA coverage and intelligibility.

\section{Modifications}

During the initial WRAP Operational Readiness Review, ORR finding SOD98-WRAP-ORR-CR-06-F-01 was generated due to PA system deficiencies. Deficiency tracking system (DTS) item number 28002080 was generated to document and track closure of these PA system deficiencies. This DTS item noted that areas exist in the plant where PA announcements are unintelligible, due to background noise and echo. Other deficiencies were later recognized, based on a comprehensive review of the PA system. Feedback was noted in several areas when PA announcements were attempted near a speaker or horn. In certain cases, critical rooms or areas within rooms had no PA system coverage. The existing PA system wiring incorrectly used the zone adapter ${ }^{2}$ as the power supply for several speakers. In addition, the PA system noise sensing amplifier ${ }^{3}$ was installed to service only approximately one-half of the available speakers in the WRAP process area (2336W Room 107), resulting in uneven PA system coverage in that area. 
HNF-5295 Rev. 0

A consultant, Brad Nelson, of Sound Solutions Northwest, was hired to evaluate PA system performance. Mr. Nelson sampled ambient sound and reverberation levels in the WRAP work areas. Based on Mr. Nelson's evaluation and the need to minimize unnecessary costs, an incremental approach was adopted for PA system improvements.

A series of improvements was identified and planned for successive implementation. Each modification was applied and then evaluated for acceptable PA system operation. Work packages WI-98-966 and WI-99-68 were generated to support PA system improvements. Table 2 - "Public Address System Improvements" lists the identified improvements and results. 
HNF-5295 Rev. 0

Table 2 - "Public Address System Improvements"

\begin{tabular}{|c|c|c|}
\hline Improvement & Description & Results \\
\hline $\begin{array}{l}\text { Adjust and Re-Aim } \\
\text { Speakers. }\end{array}$ & $\begin{array}{l}\text { Re-aim and individually adjust } \\
\text { speaker gain to minimize } \\
\text { reverberation and focus sound } \\
\text { power in work areas to improve } \\
\text { intelligibility. }\end{array}$ & $\begin{array}{l}\text { Speaker gain was adjusted to } \\
\text { improve intelligibility near } \\
\text { working areas while limiting } \\
\text { reverberation. } \\
\text { Improvement was noted, but } \\
\text { unacceptable distortion due to } \\
\text { reverberation and background } \\
\text { noise levels was still noted in all } \\
\text { WRAP work areas. }\end{array}$ \\
\hline $\begin{array}{l}\text { Install a Speech } \\
\text { Processor. } \\
\text { Work Package } \\
\text { WI-98-966 }\end{array}$ & $\begin{array}{l}\text { The speech processor applies } \\
\text { frequency shaping and dynamic } \\
\text { range compression to improve } \\
\text { intelligibility in high-noise areas. } \\
\text { The speech processor was } \\
\text { installed only for Zone } 1 \text { speakers. } \\
\text { All zone } 1 \text { speakers were re-aimed } \\
\text { and re-adjusted after the speech } \\
\text { processor was installed. }\end{array}$ & $\begin{array}{l}\text { Significant improvement was } \\
\text { noted in all Zone } 1 \text { areas. Some } \\
\text { improvement was attributed to } \\
\text { increased PA system volume } \\
\text { levels, especially in the WRAP } \\
\text { Process Area. } \\
\text { Areas were noted where } \\
\text { coverage remained marginal. }\end{array}$ \\
\hline $\begin{array}{l}\text { Add Additional } \\
\text { Speakers } \\
\text { Work Package } \\
\text { W1-99-068 }\end{array}$ & $\begin{array}{l}\text { Additional speakers were added in } \\
\text { work areas where PA system } \\
\text { coverage was marginal. } \\
\text { Speakers were added in all work } \\
\text { areas, airlock and changeroom } \\
\text { areas, and at the receiving dock. } \\
\text { Previously noted wiring problems } \\
\text { were corrected. All zone } 1 \\
\text { speakers were re-aimed and re- } \\
\text { adjusted after the modifications } \\
\text { were complete. }\end{array}$ & $\begin{array}{l}\text { Improvement was noted in all } \\
\text { areas where new speakers were } \\
\text { added. Reverberation and } \\
\text { noise still substantially affect PA } \\
\text { system operation, even in those } \\
\text { areas with added speakers. } \\
\\
\text { Industrial hygiene and safety } \\
\text { representatives performed an } \\
\text { evaluation of PA system } \\
\text { performance. }\end{array}$ \\
\hline $\begin{array}{l}\text { Install Sound } \\
\text { Absorption } \\
\text { Materials. }\end{array}$ & $\begin{array}{l}\text { Sound absorption materials can be } \\
\text { used to lower ambient noise levels } \\
\text { and reduce reverberation. }\end{array}$ & $\begin{array}{l}\text { Due to the cost and complexity } \\
\text { involved with this modification, } \\
\text { sound absorption materials } \\
\text { have not been installed at this } \\
\text { time. }\end{array}$ \\
\hline
\end{tabular}


HNF-5295 Rev. 0

\section{Evaluation}

After the work package WI-99-068 modifications were completed, an evaluation of the PA system was performed by Waste Management Hanford Federal Services $(\mathrm{WMH})$ safety and industrial hygiene personnel ${ }^{4}$. A calibrated sound level

meter ${ }^{5}$ was used to measure both background sound levels and sound levels during PA announcements. An evaluation score ranging from 1 (Unintelligible) to 4 (Easily Understood) was assigned to each location where sound measurements were taken. The evaluation results are recorded in Appendix A.

The results of the PA system evaluation indicate that announcements are quite intelligible in all administrative areas, where reverberation and background noise are minimized. Areas of distortion remain in the work areas that have high sound and reverberation levels. Sound levels were measured at less than 85 decibels in all areas where hearing protection is not currently required. 
Based on the PA system evaluation, additional modifications to increase announcement intelligibility are not warranted and would not likely be effective. Intelligibility is affected by speaker placement, speaker volume, background noise, and reverberation. In all work areas, the number of speakers exceeds the manufacturer's recommended coverage pattern ${ }^{6}$. Additional speakers cannot compensate for the high background sound and high reverberation levels found in the WRAP work areas.

Feedback was noted in calls made from the WRAP work areas, but was not noted during calls from the control room or from any other administrative areas. Feedback can be substantially reduced by minimizing telephone gain and adjusting the volume and direction of nearby speakers ${ }^{7}$. These adjustments are recommended for areas with excessive feedback. In the future, if feedback is deemed unacceptable, feedback elimination devices are commercially available. These devices typically eliminate feedback by recording each announcement and then playing it back after the announcement call is completed ${ }^{8}$.

Sound reduction and sound abatement techniques are recommended only where economically feasible. Removal and/or replacement of sound generating devices can improve PA system intelligibility. Sound abatement materials can also be installed to increase intelligibility. However, such actions are complex, lengthy, and expensive. A management analysis of available alternatives, including alternate 
means of communication, is recommended before undertaking any such modifications. Cost estimates for sound abatement materials are provided in Appendix $B$. Estimates are provided for both a minimum and maximum recommended amount of sound abatement material in each work area.

Some improvement is possible via additional speaker gain and position adjustments. A slight increase in speaker gain should increase intelligibility in certain areas, but will also increase reverberation ${ }^{9}$ in those areas. Increased speaker volume is recommended in areas where the difference between background noise and PA announcement sound levels is less than 5 decibels. Decibel readings for all areas examined are recorded in Appendix A.

Enhanced announcement techniques are recommended. Adding a series of tones to the beginning of each announcement (via the telephone keypad), speaking slowly while carefully enunciating each word, and repeating the announcement multiple times are techniques suggested for implementation. Beginning each announcement with a series of tones can alert personnel to important messages and would allow some time for personnel to move to areas near speakers, where intelligibility is improved. The PA system is sometimes used to contact specific personnel. To lessen the number of announcements, other means of communication could be used for these messages. Alternatively, preceding only high priority messages with tones would quickly alert personnel to important, facility-wide announcements. Both careful enunciation and repeating each announcement two or more times can improve comprehension. 
HNF-5295 Rev. 0

References

1 All references in this report to the "work areas" include the TRUPACT, Shipping / Receiving, NDE / NDA, and Glovebox Processing areas. This includes rooms 100, 101, 104, and 107, respectively.

2 Valcom V-2006A "Integrated Six Zone Paging Control Unit", Valcom Inc. 1111 Industry Avenue, Roanoke, VA 24013, (540) 427-3900

${ }^{3}$ Valcom V-8832 "Noise Sensing Volume Control", Valcom Inc. 1111 Industry Avenue, Roanoke, VA $24013,(540) 427-3900$

${ }^{4}$ Mr. Charies Givens, the WRAP industrial safety representative, and Mr. Edward Beck, an Industrial Hygienist, performed the evaluation.

5 Sound Level Meter, Simpson 884-2, Type S2A, Serial Number 2004580-017, Calibration date 5-24-99. A calibration check was performed during the $\mathrm{PA}$ system evaluation and the meter reading matched the level of the standard sound $(84 \mathrm{~dB})$.

${ }^{6}$ Valcom Technical Bulletin VSP-1030C/1036C Issue 6. For example, at $65-80 \mathrm{~dB}$ background noise, the recommended V-1036C 15-watt horn spacing is 75 feet, or 5,600 square feet per horn.

7 During the PA system evaluation, test calls were made from inside the Shipping and Receiving office, room 101A. This required only a slight decrease in speaker volume to minimize feedback. Similar calls were made from the receiving dock telephone, which is directly adjacent to a 15 watt horn, after only minimizing the telephone gain. Both tests indicate that a substantial reduction in feedback is possible using only minimal equipment adjustments.

8 Valcom V9963 Digital Feedback Eliminator, Valcom Inc. 1111 Industry Avenue, Roanoke, VA 24013, (540) $427-3900$.

9 Anecdotal evidence, based on responses received after prior speaker gain adjustments, suggests that increased volume levels may result in increased worker irritation with perceived sound levels. 
HNF-5295 REV. 0

\section{Appendix A - Public Address System Evaluation Results}

APPENDIX A -- PUBLIC ADDRESS SYSTEM EVALUATION RESULTS

INTRODUCTION

A-1

SOUND MEASUREMENT RESULTS

A-3

STATISTICAL EVALUATION.

A-5

MEASUREMENT Location FigurES

A-9

Introduction

This appendix documents the WRAP Public Address System evaluation performed by Mr. Charles Givens and Mr. Edward Beck on Wednesday, September 29, 1999. During the evaluation, both background sound levels and, for comparison, sound levels during Public Address (PA) announcements were measured. The personnel performing the evaluation developed a scale to indicate perceived PA system performance. This scale is shown in Table A-1 "PA System Evaluation Scale. A score of "1" on this scale indicates that, during an announcement, no spoken words were comprehensible. At the opposite end of the sale, a score of " 4 " indicates that the entire announcement is readily understood. 


\begin{tabular}{|c|l|}
\hline \multicolumn{2}{|c|}{ Table A-1 "PA System Evaluation Scale" } \\
\hline Score & \multicolumn{1}{c|}{ Description } \\
\hline 1 & The PA system is being used \\
\hline 2 & Words are detectable \\
\hline 3 & Must concentrate to understand \\
\hline 4 & Message is clear \\
\hline
\end{tabular}

The sound level measurements and evaluation scores recorded during the evaluation are listed in Table A-2 "Public Address System Evaluation Results. A location code is provided for each measurement. The location code represents a sequential identifier for each measurement taken. The location associated with each code is shown in figures A-1 through $A-9$, which are provided at the end of this appendix. 
Sound Measurement Results

\begin{tabular}{|c|c|c|c|c|}
\hline \multicolumn{5}{|c|}{ Table A-2 "Public Address System Evaluation Results" } \\
\hline $\begin{array}{c}\text { \#1 } \\
\text { Location } \\
\text { Code }\end{array}$ & $\begin{array}{c}\text { \#2 } \\
\text { Background } \\
\text { Sound Level } \\
\text { (dB) }\end{array}$ & $\begin{array}{c}\# 3 \\
\text { PA System } \\
\text { Sound Level } \\
\text { (dB) }\end{array}$ & $\begin{array}{c}\# 4 \\
\text { Change in } \\
\text { Decibels } \\
(\# 3-\# 2)\end{array}$ & $\begin{array}{c}\# 5 \\
\text { Rating } \\
(1-4)\end{array}$ \\
\hline 1 & 67 & 75 & 8 & 2 \\
\hline 2 & 65 & 73 & 8 & 3 \\
\hline 3 & 65 & 75 & 10 & 3 \\
\hline 4 & 64 & 77 & 13 & 2 \\
\hline 5 & 57 & 72 & 15 & 4 \\
\hline 6 & 63 & 77 & 14 & 2 \\
\hline 7 & 66 & 82 & 16 & 3 \\
\hline 8 & 68 & 75 & 7 & 2 \\
\hline 9 & 65 & 77 & 12 & 3 \\
\hline 10 & 66 & 83 & 17 & 4 \\
\hline 11 & 68 & 75 & 7 & 2.5 \\
\hline 12 & 77 & 78 & 1 & 2 \\
\hline 13 & 76 & 82 & 6 & 2.5 \\
\hline 14 & 76 & 80 & 4 & 3 \\
\hline 15 & 76 & 80 & 4 & 3 \\
\hline 16 & 75 & 78 & 3 & 2 \\
\hline 17 & 78 & 83 & 3 & 3 \\
\hline 17 & 81 & 87 & 6 & 3 \\
\hline 18 & 76 & 80 & 4 & 3 \\
\hline 19 & 75 & 81 & 5 & 3 \\
\hline 20 & 76 & 85 & 9 & 2 \\
\hline 21 & 76 & 84 & 8 & 3 \\
\hline 22 & 81 & 79 & -2 & 3 \\
\hline 23 & 82 & 77 & -5 & 3 \\
\hline 24 & 75 & 79 & 4 & 3 \\
\hline 25 & 66 & 75 & 9 & 4 \\
\hline 26 & 59 & 75 & 16 & 4 \\
\hline 27 & 59 & 81 & 22 & 4 \\
\hline 28 & 63 & 65 & 2 & 4 \\
\hline 29 & 55 & 71 & 16 & 4 \\
\hline 30 & 52 & 75 & 23 & 4 \\
\hline 31 & 52 & 75 & 23 & 4 \\
\hline 32 & 59 & 65 & 6 & 4 \\
\hline
\end{tabular}




\begin{tabular}{|c|c|c|c|c|}
\hline \multicolumn{5}{|c|}{ Table A-2 "Public Address System Evaluation Results" } \\
\hline $\begin{array}{c}\text { \#1 } \\
\text { Location } \\
\text { Code }\end{array}$ & $\begin{array}{c}\text { \#2 } \\
\text { Background } \\
\text { Sound Level } \\
\text { (dB) }\end{array}$ & $\begin{array}{c}\# 3 \\
\text { PA System } \\
\text { Sound Level } \\
\text { (dB) }\end{array}$ & $\begin{array}{c}\# 4 \\
\text { Change in } \\
\text { Decibels } \\
(\# 3-\# 2)\end{array}$ & $\begin{array}{c}\# 5 \\
\text { Rating } \\
(1-4)\end{array}$ \\
\hline 33 & 56 & 78 & 22 & 4 \\
\hline 34 & 50 & 79 & 29 & 4 \\
\hline 35 & 50 & 71 & 21 & 4 \\
\hline 36 & 47 & 64 & 17 & 4 \\
\hline 37 & 48 & 54 & 6 & 4 \\
\hline 38 & 49 & 70 & 21 & 4 \\
\hline 39 & 90 & 99 & 9 & 4 \\
\hline 40 & 57 & 83 & 26 & 4 \\
\hline 41 & 72 & 81 & 9 & 4 \\
\hline 42 & 48 & 70 & 22 & 4 \\
\hline 43 & 53 & 71 & 18 & 4 \\
\hline 44 & 56 & 66 & 10 & 4 \\
\hline 45 & 64 & 80 & 16 & 4 \\
\hline 46 & 64 & 82 & 18 & 4 \\
\hline 47 & 65 & 83 & 18 & 4 \\
\hline 48 & 49 & 75 & 26 & 4 \\
\hline 49 & 49 & 75 & 26 & 4 \\
\hline 50 & 56 & 77 & 21 & 4 \\
\hline 51 & 65 & 78 & 13 & 4 \\
\hline 52 & 58 & 74 & 16 & 4 \\
\hline 53 & 68 & 77 & 9 & 4 \\
\hline 54 & 67 & 75 & 8 & 2.5 \\
\hline 55 & 88 & 92 & 4 & 3 \\
\hline 56 & 90 & 97 & 7 & 4 \\
\hline 57 & 86 & 91 & 5 & 3 \\
\hline 58 & 47 & 48 & 1 & 4 \\
\hline 59 & 49 & 51 & 2 & 4 \\
\hline 60 & 43 & 59 & 16 & 4 \\
\hline 61 & 45 & 56 & $\overline{11}$ & 4 \\
\hline 62 & 51 & 53 & 2 & 3 \\
\hline 63 & 46 & 51 & 5 & 4 \\
\hline 64 & 44 & 57 & 13 & 4 \\
\hline 65 & 44 & 65 & 21 & 4 \\
\hline 66 & 43 & 54 & 11 & 4 \\
\hline 67 & 46 & 61 & 15 & 4 \\
\hline 68 & 54 & 56 & 2 & 3 \\
\hline 69 & 44 & 45 & 1 & 3 \\
\hline 70 & 43 & 72 & 29 & 4 \\
\hline
\end{tabular}


HNF-5295 REV. 0

\section{Statistical Evaluation}

The data gathered during the PA system evaluation is subjected to statistical analysis below. All statistics were calculated using Minitab for Windows, release 12.23 (Minitab Inc., (814) 238-3280).

The raw data obtained was subjected to a regression analysis.

Background noise levels (Background), reverberation levels, and speaker gain, described as raw sound levels during PA announcements and decibels above background (PA System, Delta $D B$ ) are assumed to be the primary factors affecting PA system performance. No method was available during the PA system evaluation to objectively evaluate reverberation.

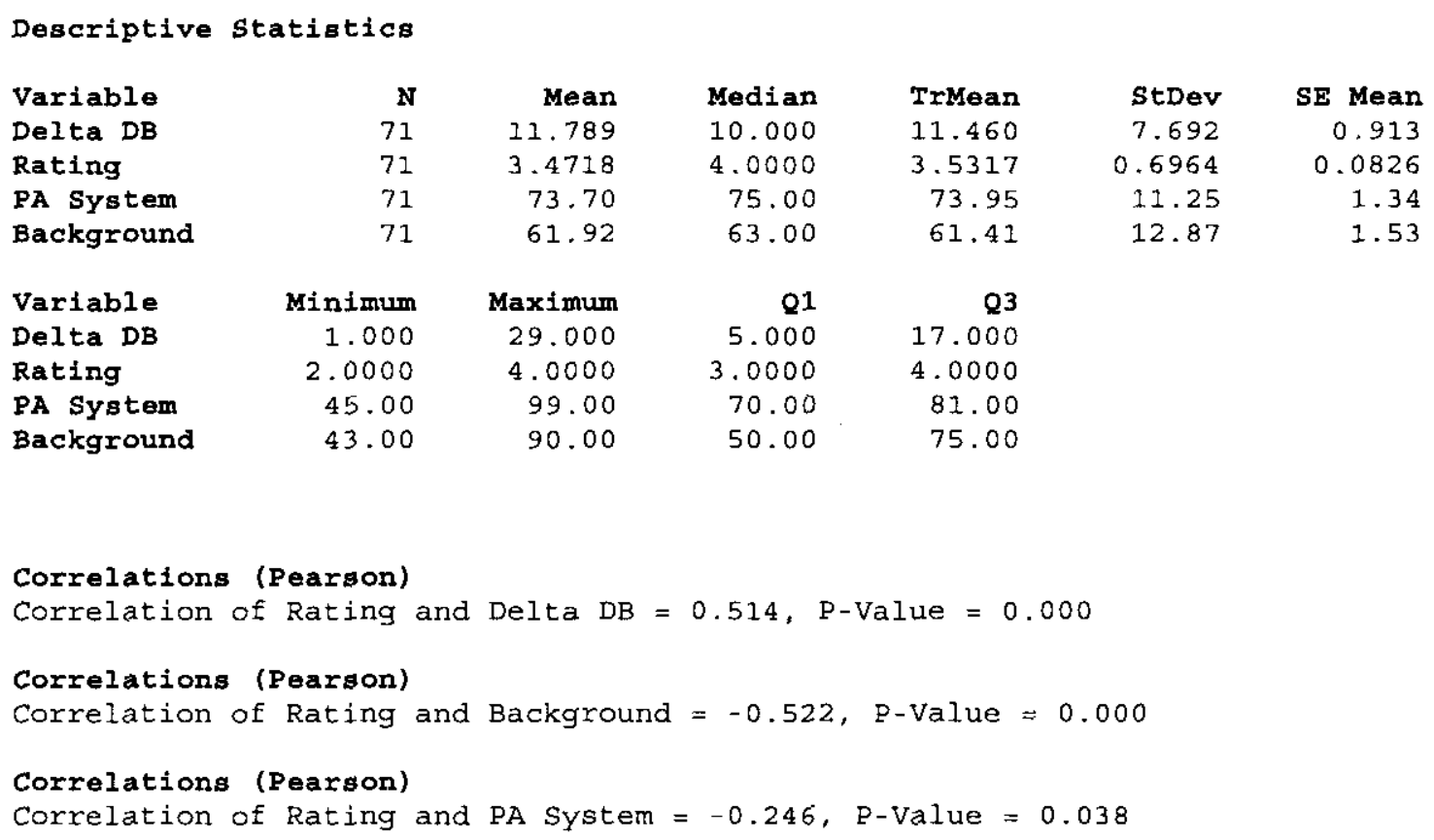

$\begin{array}{rr}\mathbf{Q 1} & \mathbf{Q 3} \\ 5.000 & 17.000 \\ 3.0000 & 4.0000 \\ 70.00 & 81.00 \\ 50.00 & 75.00\end{array}$


HNF-5295 REV. 0

\section{Regression Analysis}

The regression equation is

Rating $=2.92+0.0465$ Delta $\mathrm{DB}$

$\begin{array}{lrcrr}\text { Predictor } & \text { Coef } & \text { StDev } & T & \text { P } \\ \text { Constant } & 2.9237 & 0.1314 & 22.26 & 0.000 \\ \text { Delta DB } & 0.046496 & 0.009351 & 4.97 & 0.000 \\ S=0.6018 & \mathrm{R}-\mathrm{Sq}=26.4 \% & \mathrm{R}-\mathrm{Sq}(\mathrm{adj})=25.3 \frac{0}{6}\end{array}$

Analysis of Variance

\begin{tabular}{|c|c|c|c|c|c|c|c|}
\hline Source & DF & SS & MS & $\mathrm{F}$ & $\mathrm{P}$ & & \\
\hline Regression & 1 & 8.9540 & 8.9540 & 24.72 & 0.000 & & \\
\hline Residual Error & 69 & 24.9896 & 0.3622 & & & & \\
\hline Lack of Fit & 21 & 9.1855 & 0.4374 & 1.33 & 0.205 & & \\
\hline Pure Error & 48 & 15.8042 & 0.3293 & & & & \\
\hline Total & 70 & 33.9437 & & & & & \\
\hline \multicolumn{8}{|c|}{3 rows with no replicates } \\
\hline \multicolumn{8}{|c|}{ Unusual Observations } \\
\hline Delta $D B$ & Rating & Fit & StDev Fit & & Residual & St & Resid \\
\hline 8.0 & 2.0000 & 3.2957 & 0.0797 & & -1.2957 & & $-2.17 R$ \\
\hline 13.0 & 2.0000 & 3.5281 & 0.0723 & & -1.5281 & & $-2.56 \mathrm{R}$ \\
\hline 14.0 & 2.0000 & 3.5746 & 0.0744 & & -1.5746 & & $-2.64 R$ \\
\hline 7.0 & 2.0000 & 3.2492 & 0.0843 & & -1.2492 & & $-2.10 \mathrm{R}$ \\
\hline 9.0 & 2.0000 & 3.3422 & 0.0760 & & -1.3422 & & $-2.25 R$ \\
\hline 29.0 & 4.0000 & 4.2721 & 0.1761 & & -0.2721 & & $-0.47 x$ \\
\hline 29.0 & 4.0000 & 4.2721 & 0.1761 & & -0.2721 & & $-0.47 \times$ \\
\hline
\end{tabular}

$R$ denotes an observation with a large standardized residual

$X$ denotes an observation whose $X$ value gives it large influence.

Durbin-Watson statistic $=1.31$

No evidence of lack of fit $(P>0.1)$ 


\section{HNF-5295 REV. 0}

\section{Regression Analysis}

The regression equation is

Rating $=5.22-0.0282$ Background

$\begin{array}{lrcrr}\text { Predictor } & \text { Coef } & \text { StDev } & \mathrm{T} & \mathrm{P} \\ \text { Constant } & 5.2206 & 0.3511 & 14.87 & 0.000 \\ \text { Backgrou } & -0.028244 & 0.005554 & -5.09 & 0.000 \\ \mathrm{~S}=0.5982 & \mathrm{R}-\mathrm{Sq}=27.3 \% & \mathrm{R}-\mathrm{Sq}(\mathrm{adj})=26.2 \%\end{array}$

Analysis of Variance

$\begin{array}{lrrrrr}\text { Source } & \text { DF } & \text { SS } & \text { MS } & \text { F } & \text { P } \\ \text { Regression } & 1 & 9.2546 & 9.2546 & 25.86 & 0.000 \\ \text { Residual Error } & 69 & 24.6891 & 0.3578 & & \\ \quad \text { Lack of Fit } & 31 & 13.1557 & 0.4244 & 1.40 & 0.162 \\ \quad \text { Pure Error } & 38 & 11.5333 & 0.3035 & & \\ \text { Total } & 70 & 33.9437 & & & \end{array}$

12 rows with no replicates

Unusual Observations

$\begin{array}{rccrrrr}\text { Obs } & \text { Background } & \text { Rating } & \text { Fit } & \text { StDev Fit } & \text { Residual } & \text { St Resid } \\ 1 & 67.0 & 2.0000 & 3.3282 & 0.0764 & -1.3282 & -2.24 \mathrm{R} \\ 4 & 64.0 & 2.0000 & 3.4130 & 0.0719 & -1.4130 & -2.38 \mathrm{R} \\ 6 & 63.0 & 2.0000 & 3.4412 & 0.0712 & -1.4412 & -2.43 \mathrm{R} \\ 8 & 68.0 & 2.0000 & 3.3000 & 0.0786 & -1.3000 & -2.19 \mathrm{R} \\ 40 & 90.0 & 4.0000 & 2.6786 & 0.1714 & 1.3214 & 2.31 \mathrm{R} \\ 57 & 90.0 & 4.0000 & 2.6786 & 0.1714 & 1.3214 & 2.31 \mathrm{R}\end{array}$

$R$ denotes an observation with a large standardized residual

Durbin-Watson statistic $=1.31$

Lack of fit test

Possible curvature in variable Background (P-Value $=0.014$ )

Overall lack of fit test is significant at $P=0.014$ 


\section{Regression Analysis}

* Delta $D B$ is highly correlated with other $X$ variables

* Delta DB has been removed from the equation

The regression equation is

Rating $=4.30-0.0497$ Background +0.0306 PA System

$\begin{array}{lrcrrr}\text { Predictor } & \text { Coef } & \text { StDev } & T & \text { P } & \text { VIF } \\ \text { Constant } & 4.2991 & 0.4512 & 9.53 & 0.000 & \\ \text { Backgrou } & -0.049745 & 0.008852 & -5.62 & 0.000 & 2.8 \\ \text { PA Syste } & 0.03056 & 0.01013 & 3.02 & 0.004 & 2.8 \\ \text { S }=0.5659 & \text { R-Sq }=35.9 \% & \text { R-Sq }(\text { adj })=34.0 \% & \end{array}$

Analysis of Variance

$\begin{array}{lrrrrr}\text { Source } & \text { DF } & \text { SS } & \text { MS } & \text { F } & \text { P } \\ \text { Regression } & 2 & 12.1708 & 6.0854 & 19.01 & 0.000 \\ \text { Residual Error } & 68 & 21.7729 & 0.3202 & & \\ \quad \text { Lack of Fit } & 62 & 21.5229 & 0.3471 & 8.33 & 0.006 \\ \quad \text { Pure Error } & 6 & 0.2500 & 0.0417 & & \\ \text { Total } & 70 & 33.9437 & & & \end{array}$

60 rows with no replicates

$\begin{array}{lrr}\text { Source } & \text { DF } & \text { Seq SS } \\ \text { Backgrou } & 1 & 9.2546 \\ \text { PA Syste } & 1 & 2.9162\end{array}$

Unusual Observations

$\begin{array}{rrrrrrr}\text { Obs } & \text { Backgrou } & \text { Rating } & \text { Fit } & \text { StDev Fit } & \text { Residual } & \text { St Resid } \\ 1 & 67.0 & 2.0000 & 3.2585 & 0.0759 & -1.2585 & -2.24 \mathrm{R} \\ 4 & 64.0 & 2.0000 & 3.4689 & 0.0705 & -1.4689 & -2.62 \mathrm{R} \\ 6 & 63.0 & 2.0000 & 3.5186 & 0.0721 & -1.5186 & -2.71 \mathrm{R} \\ 8 & 68.0 & 2.0000 & 3.2088 & 0.0803 & -1.2088 & -2.16 \mathrm{R} \\ 21 & 76.0 & 2.0000 & 3.1165 & 0.1009 & -1.1165 & -2.01 \mathrm{R} \\ 40 & 90.0 & 4.0000 & 2.8479 & 0.1715 & 1.1521 & 2.14 \mathrm{R} \\ 57 & 90.0 & 4.0000 & 2.7868 & 0.1660 & 1.2132 & 2.24 \mathrm{R}\end{array}$

$\mathrm{R}$ denotes an observation with a large standardized residual

Durbin-Watson statistic $=1.50$

Lack of fit test

Possible curvature in variable Backgrou (P-Value $=0.046$ )

Possible curvature in variable PA syste (P-Value $=0.001$ )

Overall lack of fit test is significant at $P=0.001$

$R$ denotes an observation with a large standardized residual 


\section{Measurement Location Figures}

The nine figures that follow document the locations at which sound level measurements were taken. A total of 71 measurements were taken at 70 unique locations at both the $2336 \mathrm{~W}$ and $2740 \mathrm{~W}$ buildings. Table $A-2$ "Public Address System Evaluation Results" documents the sound levels recorded at each location. The numbers shown in each diagram correspond to the "Location Code" provided in Table A-2.

While measurements were being taken in the WRAP Process Area (2336W Room 107) at location \#17, sound levels abruptly changed due to equipment operation in that area. To indicate the extent of sound level change, two separate measurements were taken at that location. 
HNF-5295 REV. 0

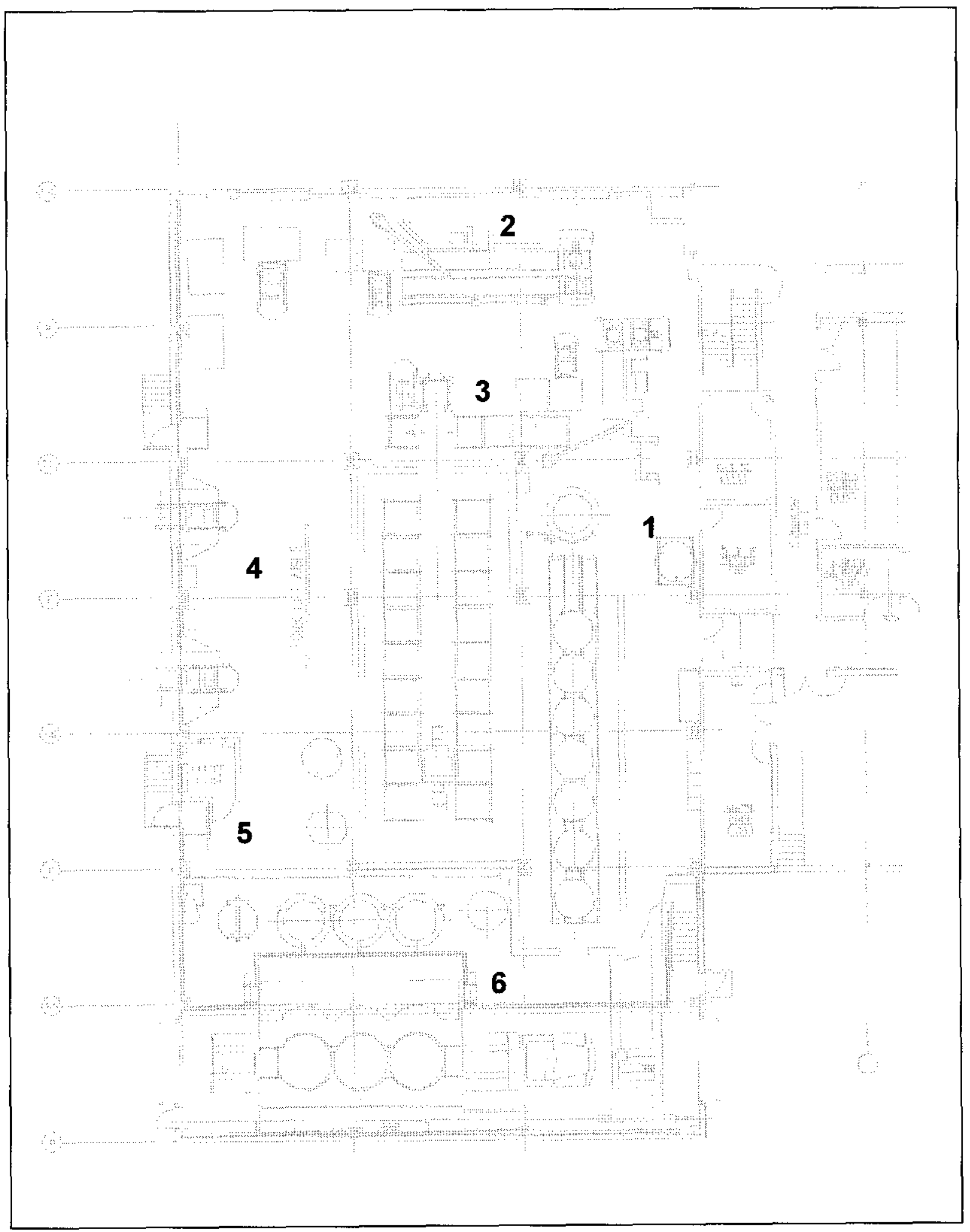

Figure A-I -- WRAP Shipping / Receiving Area 
HNF-5295 REV. 0

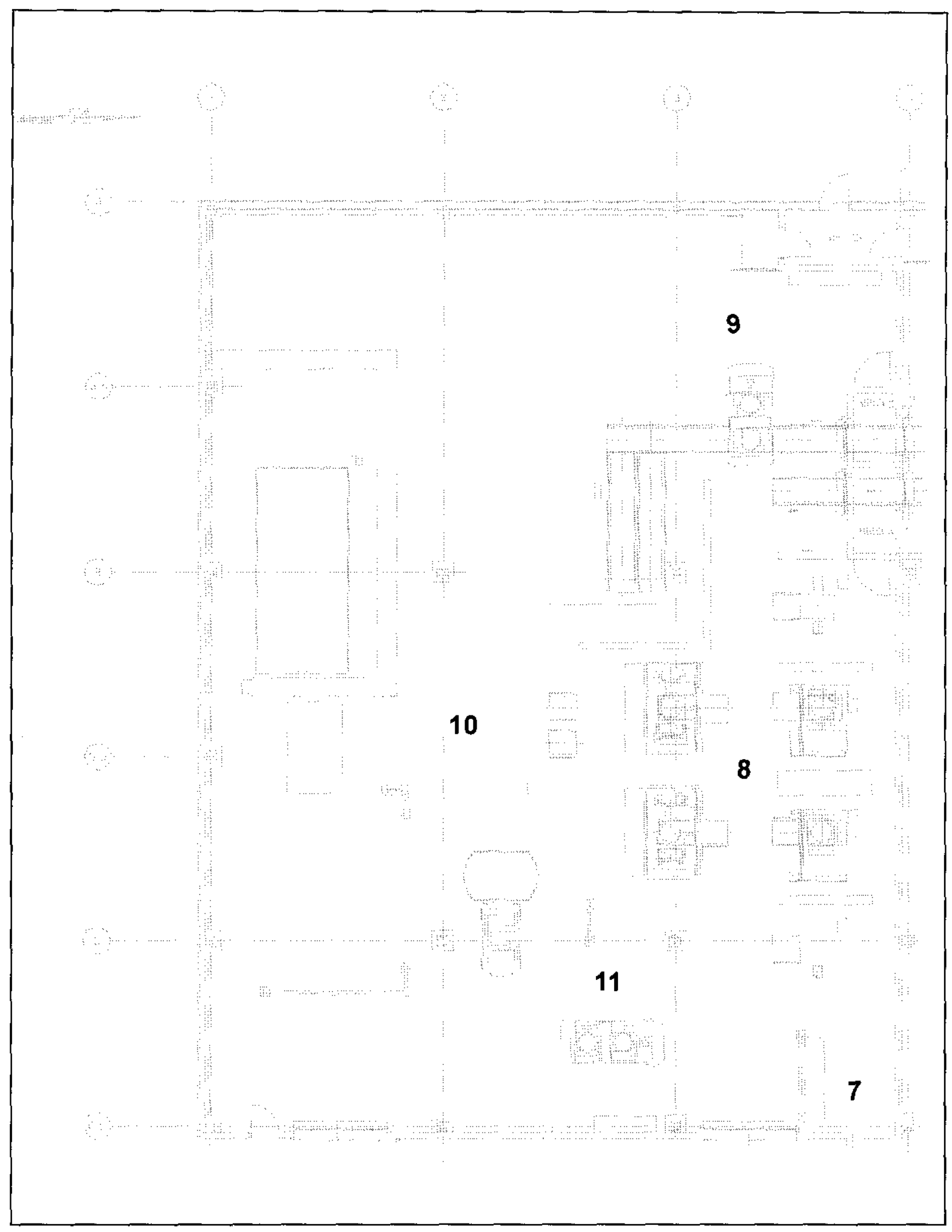

Figure A-2 -- WRAP NDE/NDA Area 
HNF-5295 REV. 0

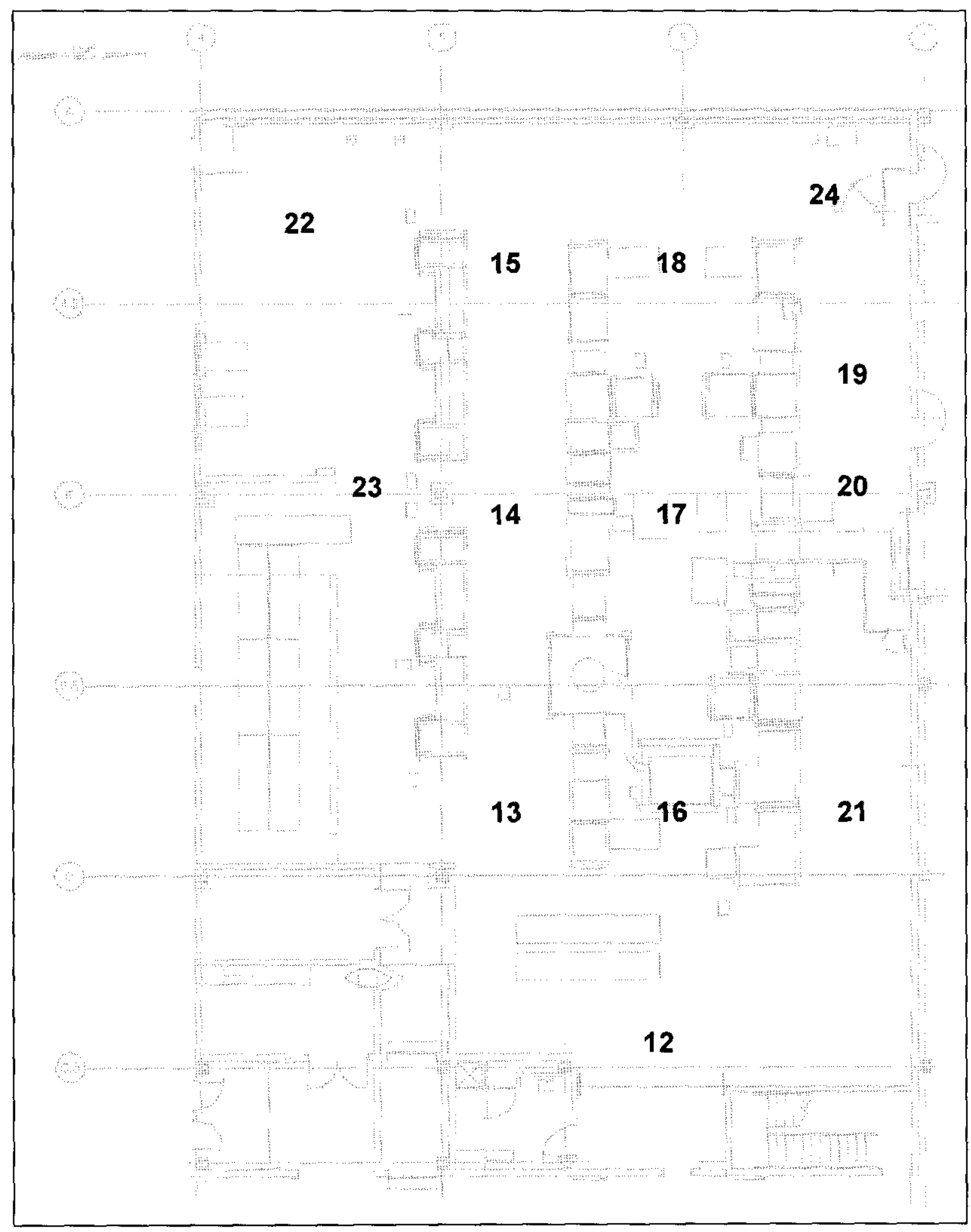

Figure A-3 -- WRAP Process Area 
HNF-5295 REV. 0

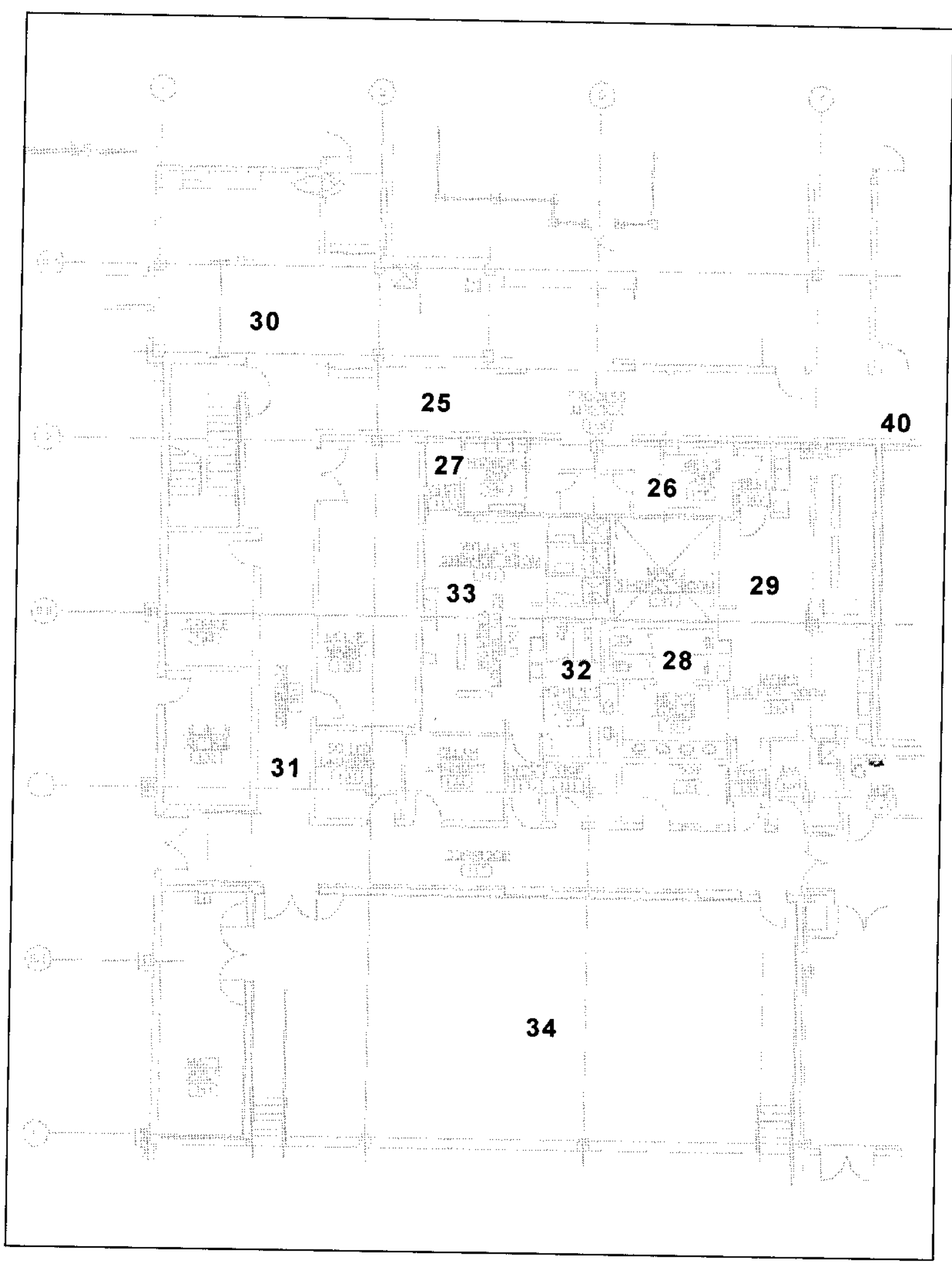

Figure A-4 -- WRAP Work and Storage Areas 
HNF-5295 REV. 0

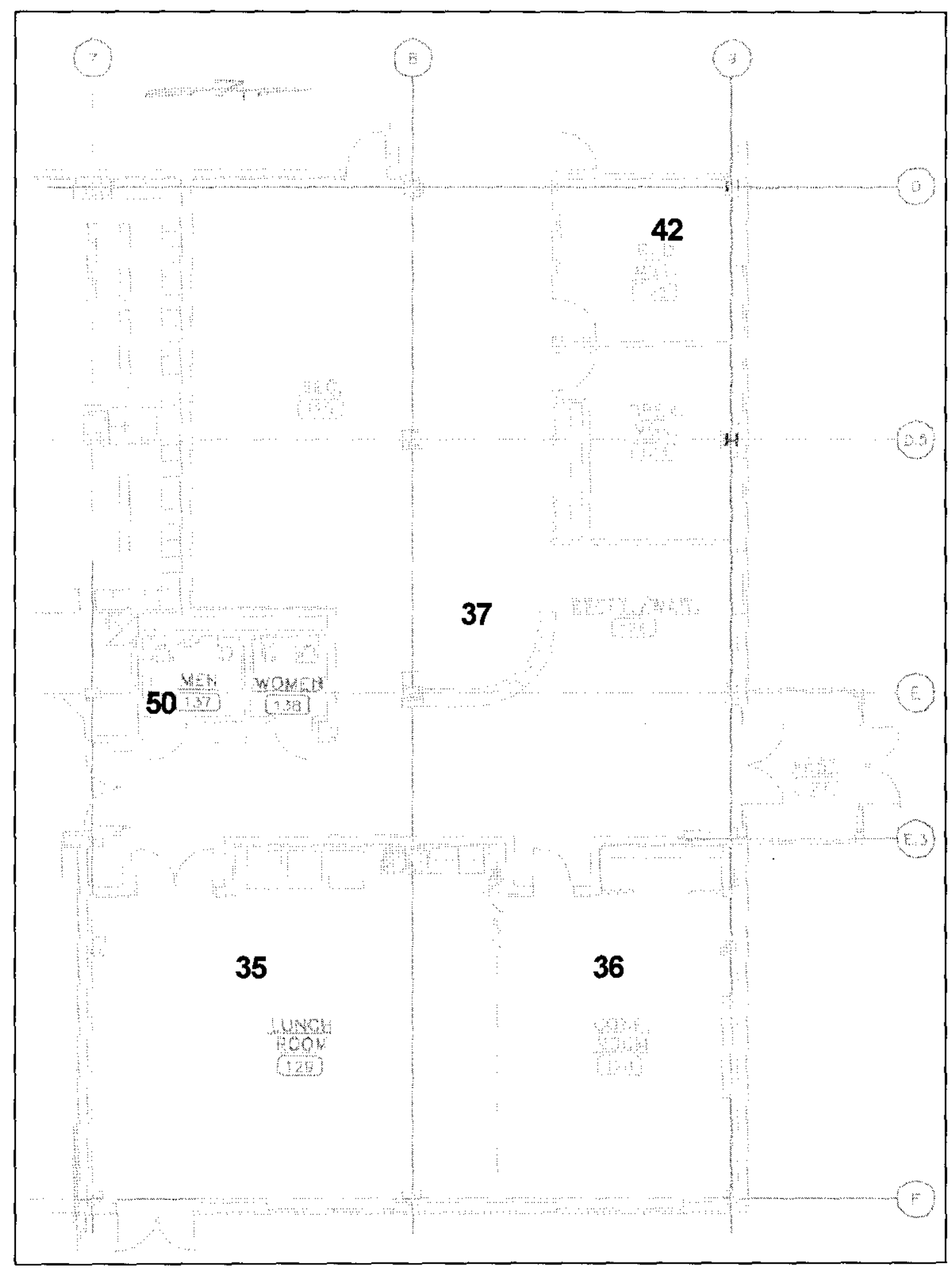

Figure A-5 -- WRAP Administrative Areas 
HNF-5295 REV. 0

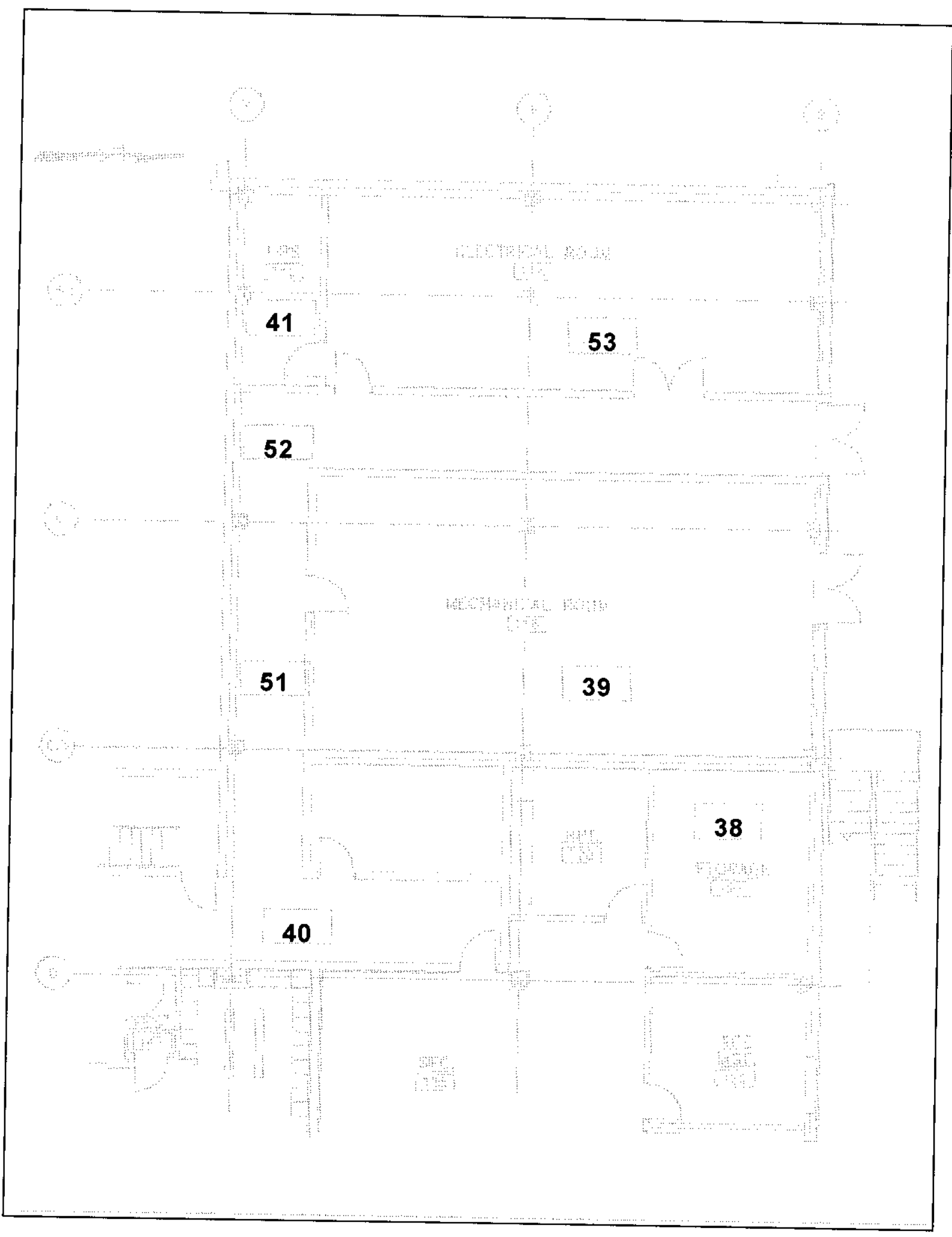

Figure A-6 -- WRAP Mechanical, Electrical, and Storage Areas 
HNF-5295 REV. 0

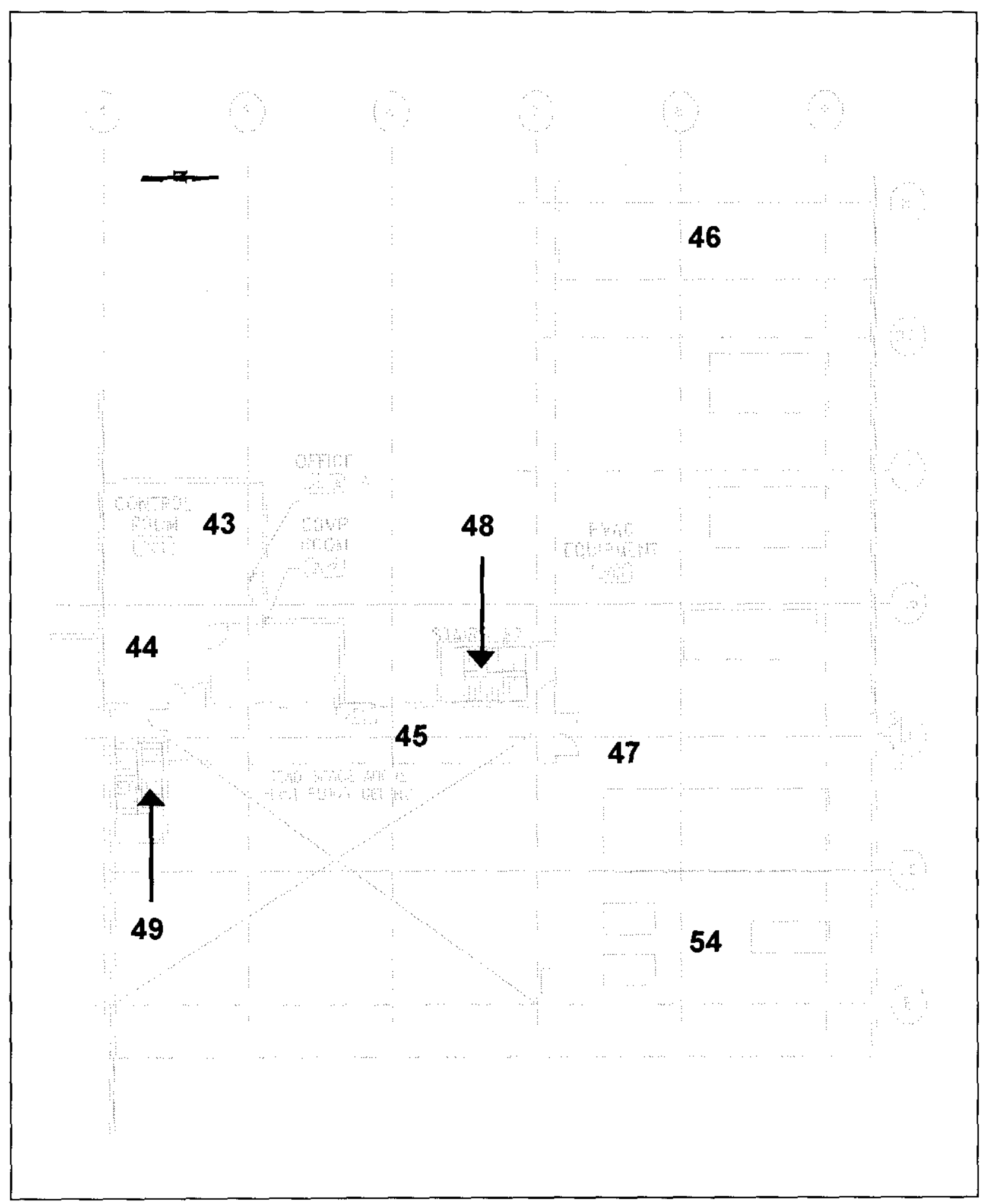

Figure A-7 -- WRAP Upper Level 
HNF-5295 REV. 0

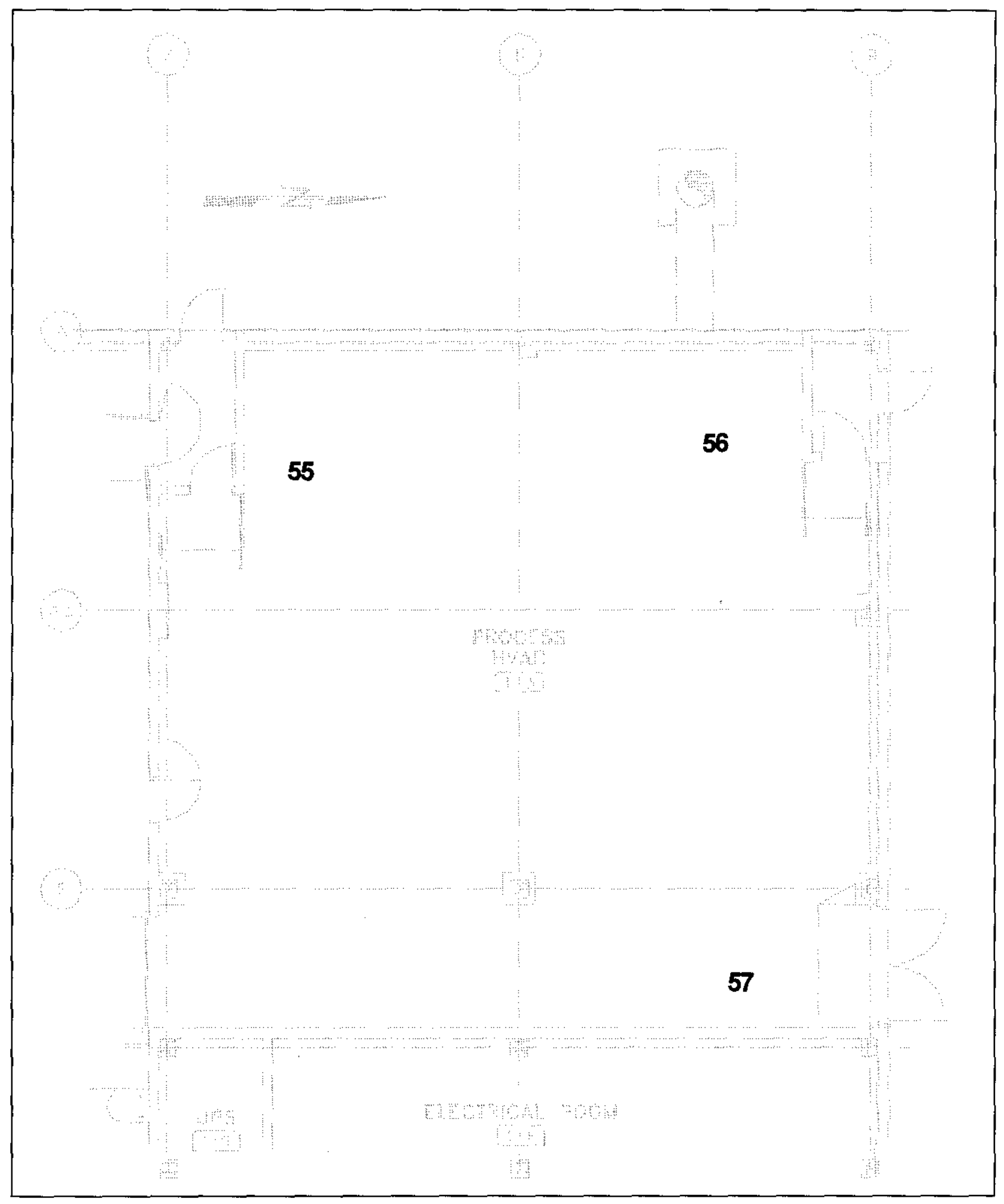

Figure A-8 -- WRAP Process HVAC Area 
HNF-5295 REV. 0

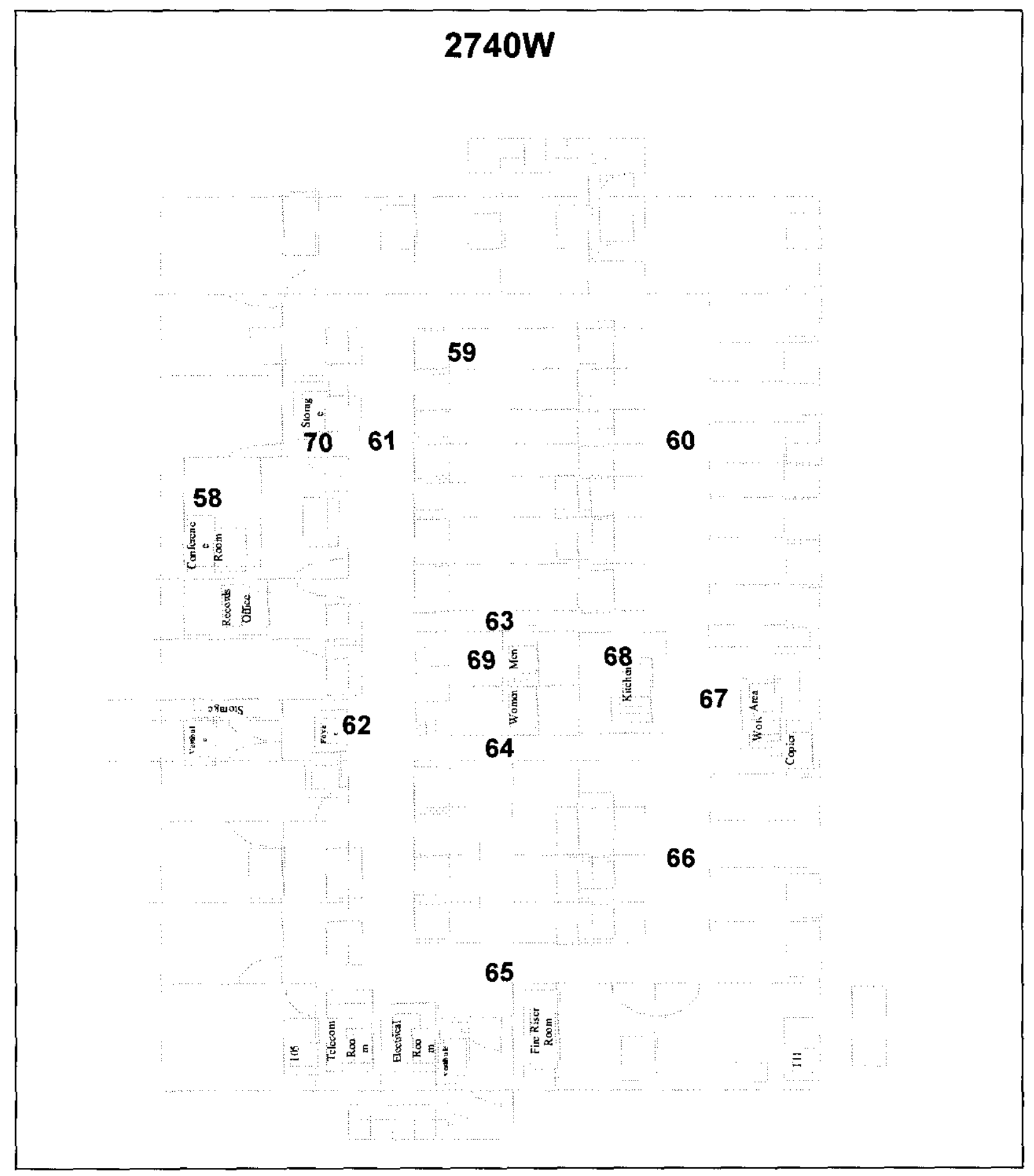

Figure A-9 2740W Administrative Office Building 
HNF-5295 REV. 0

\section{Appendix B - Public Address System Correspondence}

APPENDIX B -- PUBLIC ADDRESS SYSTEM CORRESPONDENCE.

INTRODUCTION B-1

SOUND ABSORPTION COST ESTIMATES B-2

PUBLIC ADDRESS REVIEW B-5

SPEECH PROCESSOR DATA B-7

\section{Introduction}

This appendix contains the informal correspondence received from a speech processor vendor and also from the consultant hired to review the WRAP public address system. The correspondence includes public address system background information, recommendations for PA system modifications, price estimates for sound abatement material, and technical specifications for the speech processor installed at WRAP. 


\section{Sound Absorption Cost Estimates}

\section{SOUND ((fi sOLUTIONS}

WASTE MANAGEMENT - HANFORD

WRAP \#1 FACILITY

ACOUSTIC TREATMENT RECOMMENDATIONS

\section{- NDE / NDA}

The minimum recommended treatment is to add approximately 1200 Sabines of absorption, as measured in the $2 \mathrm{kHz}$ octave band. This correlates to the following square-footage of materials.

\begin{tabular}{|l|l|l|l|r|}
\hline Manufacturer / Item & Area Required & $\begin{array}{l}\text { Number of } \\
\text { Baffles }\end{array}$ & $\begin{array}{l}\text { Sabines } \\
(\mathbf{2 K H z})\end{array}$ & Est. Cost \\
\hline $\begin{array}{l}\text { Acoustical Solutions } \\
\text { AQFA-10 }\end{array}$ & $2144 \mathrm{SF}$ & 67 & $1222 \mathrm{Sa}$ & $\$ 9,400$ \\
\hline Netwell USDA & $1000 \mathrm{SF}$ & 125 & $1210 \mathrm{Sa}$ & $\$ 5,000$ \\
\hline
\end{tabular}

The maximum recommended treatment is to add approximately 2000 Sabines of absorption, as measured in the $2 \mathrm{kHz}$ octave band. This correlates to the following square-footage of materials.

\begin{tabular}{||l|l|l|l|r||}
\hline Manufacturer / Item & Area Required & $\begin{array}{l}\text { Number of } \\
\text { Baffles }\end{array}$ & $\begin{array}{l}\text { Sabines } \\
(2 \mathrm{KHz})\end{array}$ & Est. Cost \\
\hline $\begin{array}{l}\text { Acoustical Solutions } \\
\text { AQFA-10 }\end{array}$ & $3584 \mathrm{SF}$ & 112 & $2043 \mathrm{Sa}$ & $\$ 15,600$ \\
\hline Netwell USDA & $1680 \mathrm{SF}$ & 210 & $2033 \mathrm{Sa}$ & $\$ 8,400$ \\
\hline
\end{tabular}

3030 West Clearwater Avenue, Suite 205 Kennewick, Washington 99336

509-783-8272 1-800-962-2720 FAX 509-783-8350 


\section{- Shipping / Receiving}

The minimum recommended treatment is to add approximately 1200 Sabines of absorption, as measured in the $2 \mathrm{kHz}$ octave band. This correlates to the following square-footage of materials.

\begin{tabular}{|l|l|l|l|r|}
\hline Manufacturer / Item & Area Required & $\begin{array}{l}\text { Number of } \\
\text { Baffles }\end{array}$ & $\begin{array}{l}\text { Sabines } \\
\mathbf{( 2 \mathrm { KHz } )}\end{array}$ & Est. Cost \\
\hline $\begin{array}{l}\text { Acoustical Solutions } \\
\text { AQFA-10 }\end{array}$ & $2144 \mathrm{SF}$ & 67 & $1222 \mathrm{Sa}$ & $\$ 9,400$ \\
\hline Netwell USDA & $1000 \mathrm{SF}$ & 125 & $1210 \mathrm{Sa}$ & $\$ 5,000$ \\
\hline
\end{tabular}

The maximum recommended treatment is to add approximately $2300-2400$ Sabines of absorption, as measured in the $2 \mathrm{kHz}$ octave band. This correlates to the following squarefootage of materials.

\begin{tabular}{|l|l|l|l|r|}
\hline Manufacturer $/$ Item & Area Required & $\begin{array}{l}\text { Number of } \\
\text { Baffles }\end{array}$ & $\begin{array}{l}\text { Sabines } \\
\mathbf{( 2 K H z )}\end{array}$ & Est. Cost \\
\hline $\begin{array}{l}\text { Acoustical Solutions } \\
\text { AQFA-10 }\end{array}$ & $4160 \mathrm{SF}$ & 130 & $2280 \mathrm{Sa}$ & $\$ 18,100$ \\
\hline Netwell USDA & $2000 \mathrm{SF}$ & 250 & $2420 \mathrm{Sa}$ & $\$ 10,000$ \\
\hline
\end{tabular}

3030 West Clearwater Avenue, Suite 205 Kennewick, Washington 99336 


\section{- Processing}

The minimum recommended treatment is to add approximately 1800 Sabines of absorption, as measured in the $2 \mathrm{kHz}$ octave band. This correlates to the following square-footage of materials.

\begin{tabular}{|l|l|l|l|r|}
\hline Manufacturer I Item & Area Required & $\begin{array}{l}\text { Number of } \\
\text { Baffles }\end{array}$ & $\begin{array}{l}\text { Sabines } \\
(\mathbf{2 K H z})\end{array}$ & Est. Cost \\
\hline $\begin{array}{l}\text { Acoustical Solutions } \\
\text { AQFA-10 }\end{array}$ & $3136 \mathrm{SF}$ & 98 & $1788 \mathrm{Sa}$ & $\$ 13,600$ \\
\hline Netwell USDA & $1480 \mathrm{SF}$ & 185 & $1791 \mathrm{Sa}$ & $\$ 7,400$ \\
\hline
\end{tabular}

The maximum recommended treatment is to add approximately 2700 Sabines of absorption, as measured in the $2 \mathrm{kHz}$ octave band. This correlates to the following square-footage of materials.

\begin{tabular}{|l|l|l|l|r|}
\hline Manufacturer/Item & Area Required & $\begin{array}{l}\text { Number of } \\
\text { Baffles }\end{array}$ & $\begin{array}{l}\text { Sabines } \\
(\mathbf{2 K H z})\end{array}$ & Est. Cost \\
\hline $\begin{array}{l}\text { Acoustical Solutions } \\
\text { AQFA-10 }\end{array}$ & $4768 \mathrm{SF}$ & 149 & $2718 \mathrm{Sa}$ & $\$ 20,700$ \\
\hline Netwell USDA & $2240 \mathrm{SF}$ & 280 & $2710 \mathrm{Sa}$ & $\$ 11,200$ \\
\hline
\end{tabular}

The option has been raised of using a combination barrier/absorber to both reduce the noise emitted by the machinery in Processing, and reduce the reverberant field and reverberation time. This concept would use baffles hung directly around or draped over the machinery, which would then be move as needed for operation or maintenance. This idea has merit, though it may be cost prohibitive. From a purely acoustical analysis standpoint, the following quantities would be required.

The minimum recommended treatment is to add approximately 1800 Sabines of absorption, as measured in the $2 \mathrm{kHz}$ octave band. This correlates to the following square-footage of materials.

\begin{tabular}{|l|l|l|l|c|}
\hline Manufacturer / Item & Area Required & $\begin{array}{l}\text { Number of } \\
\text { Baffles }\end{array}$ & $\begin{array}{l}\text { Sabines } \\
(\mathbf{2 K H z})\end{array}$ & Est. Cost \\
\hline $\begin{array}{l}\text { Acoustical Solutions } \\
\text { ABSC-25 }\end{array}$ & $3360 \mathrm{SF}$ & 105 & $1780 \mathrm{Sa}$ & $\$ 26,700$ \\
\hline
\end{tabular}

The maximum recommended treatment is to add approximately 2700 Sabines of absorption, as measured in the $2 \mathrm{kHz}$ octave band. This correlates to the following square-footage of materials.

\begin{tabular}{|l|l|l|l|r|}
\hline Manufacturer / Item & Area Required & $\begin{array}{l}\text { Number of } \\
\text { Baffles }\end{array}$ & $\begin{array}{l}\text { Sabines } \\
(\mathbf{2 K H z})\end{array}$ & Est. Cost \\
\hline $\begin{array}{l}\text { Acoustical Solutions } \\
\text { ABSC-25 }\end{array}$ & 5120 SF & 160 & $2714 \mathrm{Sa}$ & $\$ 40,650$ \\
\hline
\end{tabular}

3030 West Clearwater Avenue, Suite 205 Kennewick, Washington 99336

509-783-8272 1-800-962-2720 FAX 509-783-8350 


\section{Public Address Review}

Sound Solutions Nortbwest, Ine.

3030 W. Clearwater Ave., Suite 205

Kennewick, WA 99336

\section{Transmittal Cover Sheet}

$\begin{array}{llll}\text { DATE: } & 24 \text { August } 1998 & \text { TIME: } & 11: 30 \text { AM } \\ \text { TO: } & \begin{array}{l}\text { Michael Lane } \\ \text { Waste Management - Hanford }\end{array} & \begin{array}{l}\text { PHONE: } \\ \text { FAX: }\end{array} & \begin{array}{l}373-1341 \\ 373-3891\end{array} \\ & & \text { PHONE: } & 509 / 783-8272 \\ \text { FROM: } & \text { Brad Nelson } & \text { FAX: } & 509 / 783-8350 \\ & & & \\ \text { RE: } & \text { Preliminary findings for PAX system } & \\ \text { CC: } & \text { File } & \end{array}$

Number of pages including cover sheet: 2

Message

Michael,

As we discussed the purpose of this letter is to update Waste Management - Hanford of preliminary concepts for improving the PAX system at WRAP 1 l. A more formal report of findings, with test data, will follow. The informetion in this letter should be sufficient to give direction for initial action to inprove the PAX system.

The complaint regarding the PAX system in the four rooms we tested, and a fifth room which was not tested. was that the announcements could not be urderstood, due to room conditions. Before I address the specinic issues with each room, let me give gome general guidelines with pertnin to the paging systems and intelligibility. In brief, speech intelligibility is degraded by high noise levels and long reverberation decay times (RT60), with the resulting high reverberant field levels $\left(L_{R}\right)$ in the s0om. These two conditions, in varying degrees, were found in all the rooms we tested.

If the noise level is the main cause of poor intelligibility, a hom can usually be adjusted or replaced to provide a higher paging level. However, the PAX system at WRAP uses paging horns with built-in amplifiers, which places constraints upon the extent of upgrade possible. In the high noise areas, 15W homs are being used, which is the highest power hom available from Valcom using the 24VDC power supplies in place. To increase the hom capability would require stepping up to Valcom's $30 \mathrm{~W}$ amplified hom, which must have a $48 \mathrm{VDC}$ power supply. The PAX wiring layout may not casily allow this change. Altematively, it is possible to add speech processing to improve the speech intelligibility, without increasing the output power.

If long $R T 60$ s and high $L_{R}$ are the main problem, the intelligibility might be improved by electronic or electro-acoustic means, though acoustic problems can only be truly addressed with acoustic solutions. There are a number of things to do which may improve the general PAX intelligibility. 1.) Aim the homs directly into the work areas. Acouscic energy which is allowed to bounce off the walls will only contribute to the $L_{R}$ and reduce the inteltigibility. 2.) Relocate any homs which do not have clear coverage of a work area. The homs in use will cover an angle of $120^{\circ}$ horizontal by $90^{\circ}$ vertical. The homs should be relocated or re-simed so that as much of this energy is sent directly into the work area. 3.) Eliminate any

Figure B-1 -- Initial PA System Correspondence Sheet 1 of 2 
homs which are not necessary. When reverberation is problematic, more horns creates more problems. Horns which do not provide beneficial acoustic energy to any given listener will only drive the reverberant field, as perceived by that listener. 4.) Speech processing can be used to improve the intelligibility. The compromise is that the resulting sound will not be natural sounding. 5.) Add acoustic absorption to the rooms to reduce both the reverberation time and the reverberant field level.

First, in NDE/NDA, the noise level was significant, however, the PAX system was delivering suffictent sourid pressure level to overcome the ambient noise level. The primary cause of poor speech intelligibility in NDE/NDA was the long reverberation time. Though electronic speech processing can assist the PAX system, acoustic problems should be addressed with acoustic solutions. This means that absorptive materials should be added to the room to shorted the reverberation time and reduce the reverberant field Jevel. When this is done in an industrial facility, there are immediate concerns relating to fire codes, et. al. A number of acoustic material companies have met with this challenge and produced absorptive materials with are appropriate for use in a facility such as WRAP. One example of this is the Peer Almute paneling. This is an aluminum panel which is designed to have certain acoustical properties. The brochure and sample I gave you last Friday will help to illustrate how this material could be implemented. Also as we discussed, it would not be necessary to cover entire walls or the ceiling with absorptive treatment, though the extent of treatment needed is yet to be determined.

Second, in Shipping/Receiving, tho site conditions are much the same. The paging horns should be reaimed or moved. As well, acoustic treatment should be considered.

Third, in the HVAC room, high noise levels were measured. However, this noise was primarily low frequency noise. The spectral conient was not such that it would interfere with speech intelligibility. Though the room had mostly hard, reflective surfaces, it was not of a size to allow the build-up of a problematic reverberant field. As a result, I would advise that nothing needs to be done in the HVAC room other than possibly moving and re-aining the horns to properly cover the work area.

Lastly, the Processing area will present the greatest challenges. With the machinery operating, both the noise level and reverberation are problems. The ambient noise sensing / gain control system that is in place is functioning, but isn't providing enough level increase to compensate for the added noise while machinery is operating. Either it is not capable of providing enough gain, or it is not quite set properly. Relocation and re-aiming of horns will be of help here. As well, acoustic treatment is the best means of reducing the interference of the reverberant field with speech. A speech processor would be wish to help cur through the machinery noise.

The speech processor I mentioned is made by Communications Company Inc. It is the SP-1 processor. This could be installed in line with the speakers, similar to the noise sensing equipment in the Processing Room. Or it may be installed in the Communications Room, with the PAX equipment. If installed here, all the speakers on a given zone will be processed. Those speakers in low noise areas of the PAX zone will be very intelligible, but not sound natural.

I am enclosing information on the Communications Company Inc. SP-I processor. I will get cost info to you as soon as I have it compiled. We should also discuss this preliminary letter, so I can answer any questions that you all may have. As to specifics of relocating horns or calculating the amount of absorption needed, I would need to have some further data on the rooms, such as dimensions and a djagram of room layout showing work areas.

I will be out of the office for part of the afternoon, but you can leave a message or send me an e-mail ssnwine@3-cities.com. I am also out of town tomorrow morning.

Thanks for all your help.

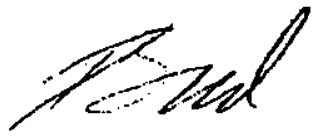

Figure B-2 -- Public Address Review Sheet 2 of 2 
Speech Processor Data

DATE: 8/24/98

TIME: 3:14pm

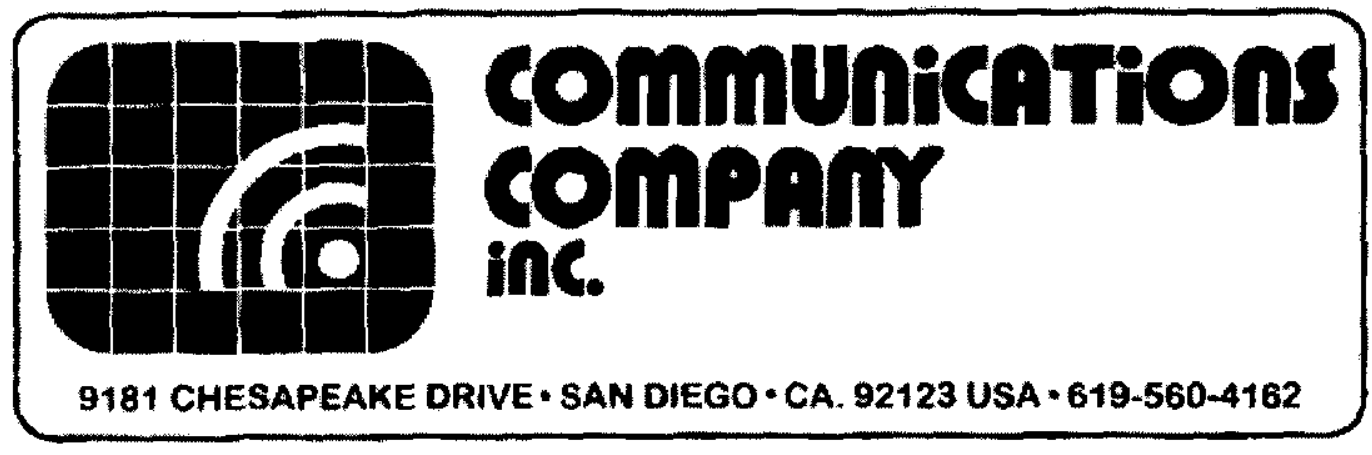

FAX TRANSMISSION FORM

To: Mike Lane

FROM: ROBB HARVEY

COMPANY:

NO. PAGES: 2

FAX NUMBER: 509-373-3891

CONF. COPY TO FOLLOW IN MAIL:

NO

CONF. OF TRANSMISSION REQUIRED:

NO

NOTES: Attached is the literature that you requested. If you have any questions or need additional information, please call.

Thanks,

$$
\text { Robb Harvey }
$$

IF ALL PAGES OF THIS FAX TRANSMISSION ARE NOT RECEIVED PLEASE CALL 619-560-4162

Figure B-3 -- Sound Processor Data Sheet 1 of 2 


\section{SPEECH PROCESSOR}

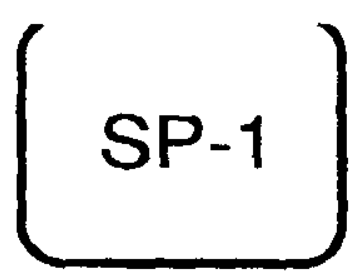

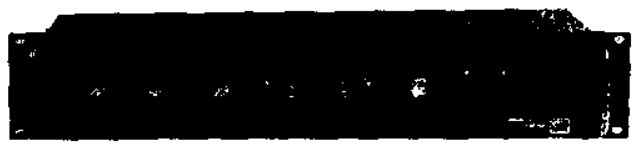

DESCRIPTION

The SP-1 Spoech Processor can enhance the intelliglbil hy of speech for listeners in a nolsy onvironment as much as six times the peak audio power. Adapted from the flioht deck announcing system on US Navy aireraft carriers. it is a costsfiective way to improve coverage of Grand Pitix car reces. factory foors, or any hiph noise area. The SP-1 applies a combination of trequency shaping and dynamic range compression by single sidaband clipping. The processing can be switched in from the front panel or remotely for beckoround music/paging applications. A 7 hertz frequency shitt can be selected for control of acoustic feedback. Input is a $600 \mathrm{ohm}$ line or a low impedance microphone; output is at $600 \mathrm{ohm}$ line lovel.

\section{SPECIFICATIONS}

Typo: Speech processor using adjustable peak clipping of a lower sideband signal at a suppressed cartier frequency of $25 \mathrm{xHz}$.

Frequency response: Optimized for Intelliglbillty whth SSB clipping: 6 dB/octave pre-emphasls up to a broad poak from 1500 to $3100 \mathrm{~Hz}, 18 \mathrm{~dB} /$ octave rolloff above $3400 \mathrm{~Hz}$. Flat response when processing is not selected.

Output: Continuously adjustable from 0 to 10 volts peak into 600 ohms (19 dBm)

Line Input: Input impedance 10 kilohms for bridging across 600 ohm line. $600 \mathrm{mV}$ peak ( $-5 \mathrm{dBm}$ re $600 \mathrm{ohms}$ ) with tine lovel control at maximum will give correct calibration of CLIPPING control.

Microphone Input: $0.6 \mathrm{mV}$ peak with microphone lovel control at maximum will give correct calibration of

CLIPPING control. Input impedance greater than 2 kilohms above $50 \mathrm{~Hz}$. $200 \mathrm{de}$ pad solectable on rear panel for highsensitivity microphones.

Frectuency shith: When selected, all frequencies are shimed upward by $7 \mathrm{~Hz}$ for control of acoustle feedoack.

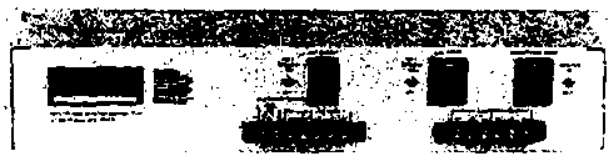

Remote selectlon of processing: Contact closure to ground, or floating 24 Vdc $10 \mathrm{~mA}$ source.

Front panel controls:

Line level: Continuously varlable potentiometer for $600 \mathrm{ohm}$ line input.

Mic lovel: Continuously variable potentometer for low impedance microphone input.

Cripping (dB): Continuousty vartable over $30 \mathrm{~dB}$

range. With CLIPPING control set at mid scale (12dB), MICROPHONE LEVEL or LINE LEVEL is adjusted for

$12 \mathrm{~dB}$ clipping as read on LED bar graph. CLIPPING

control can then be used to select the amount of clippirg desired. Peak output tevet will stay

approximately the same when processing is switched

in or out.

Output: Continuously variable trom 0 to 10 volts peak. Procesaing IN or OUT/REMOTE switch.

7-Hz irequency shin iN or DUT awteh.

Displey brightness: Screwdriver adjusiment on front

panel tor CLIPPING and OUTPUT L.ED bar graphs.

Power ON/OFF switch.

Rear panel controls: Mic Level pad: switchable in or out. Line input: pin 1 ground, switchable on or off. Line output: pin 1 ground, switchable on or oft.

Displays: Two 10-5egment LED bar graphs, one for CLIPPING $(-3 \mathrm{~dB}$ to over $+24 \mathrm{~dB})$, one tor peak OUTPUT (-9 dBm to over $+18 \mathrm{dBm}$ ). Each display has 5 green. 3 yoliow, and 2 rod segments.

Connectors: Microphone input: 3 pin XLR female, screw terminal. Line input: 3 pin XLR fernale, screw ferminal. Line output: 3 pin XLR male, screw terminal. Processor in out remote control: screw teminal.

Power required: $117 \mathrm{Vac}, 50 / 60 \mathrm{~Hz}, 11$ watts Mounting: $31 / 2^{-} \times 19^{-4}$ rack mount

Oimensions: 31/2" high, 19" wide, 83/8" deep Wolght: $7.5 \mathrm{lbs}$.

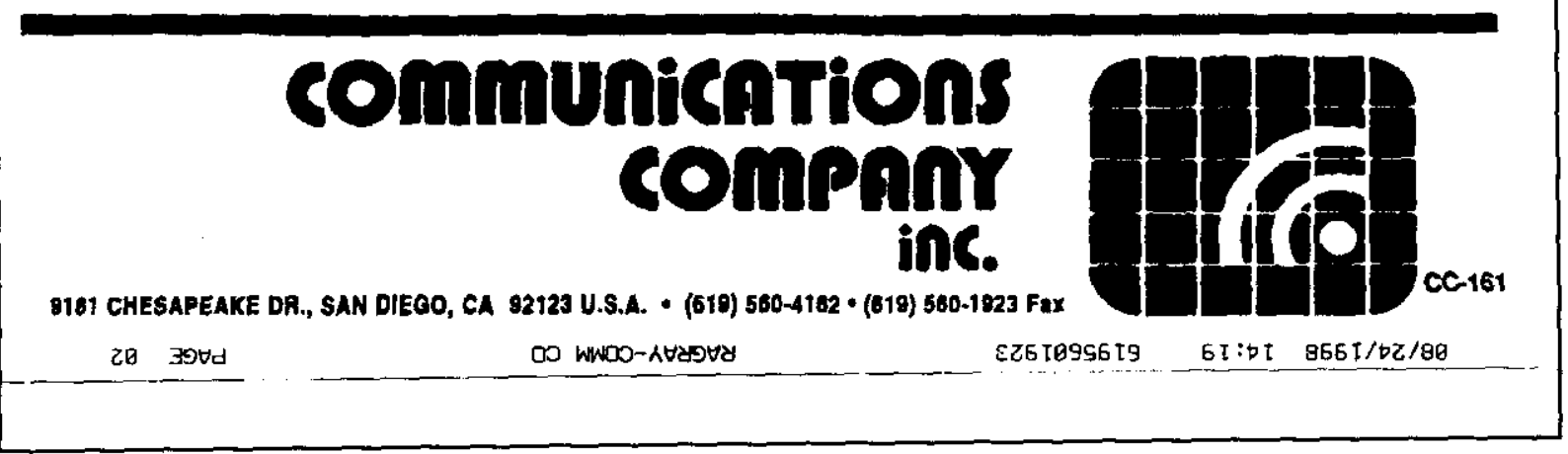

Figure B-4 -- Speech Processor Data Sheet 2 of 2 


\begin{tabular}{|c|c|c|c|c|c|}
\hline \multicolumn{6}{|c|}{ DISTRIBUTION SHEET } \\
\hline To & \multirow{2}{*}{\multicolumn{3}{|c|}{$\begin{array}{l}\text { From } \\
\text { WRAP Engineering }\end{array}$}} & \multicolumn{2}{|l|}{ Page 1 of 1} \\
\hline Distribution & & & & \multicolumn{2}{|c|}{ Date $10 / 21 / 99$} \\
\hline \multicolumn{4}{|l|}{ Project Title/Work Order } & \multicolumn{2}{|l|}{ EDT No. $N / A$} \\
\hline WRAP PA SYSTEM REVIEW FINDINGS, & \multicolumn{2}{|c|}{ HNF-5295, REV. 0} & & \multicolumn{2}{|c|}{ ECN No. EDT-623539 } \\
\hline Name & MSIN & $\begin{array}{c}\text { Text } \\
\text { With All } \\
\text { Attach. }\end{array}$ & Text Only & $\begin{array}{l}\text { Attach./ } \\
\text { Appendix } \\
\text { Only }\end{array}$ & $\begin{array}{l}\text { EDT/ECN } \\
\text { Only }\end{array}$ \\
\hline
\end{tabular}

KL Humphrys

JK Kersten

MP Lane

RE Mitchell

CE Taylor

JR Weidert

DOE/RL Reading Room

Engineering Files
T5-52 X

T4-52 X

T4-52

X

T4-52

$X$

T4-52

$\mathrm{X}$
T4-52 X

H2-53 X

B1-07 $X$ 